DIW BERLIN

Discussion

Papers
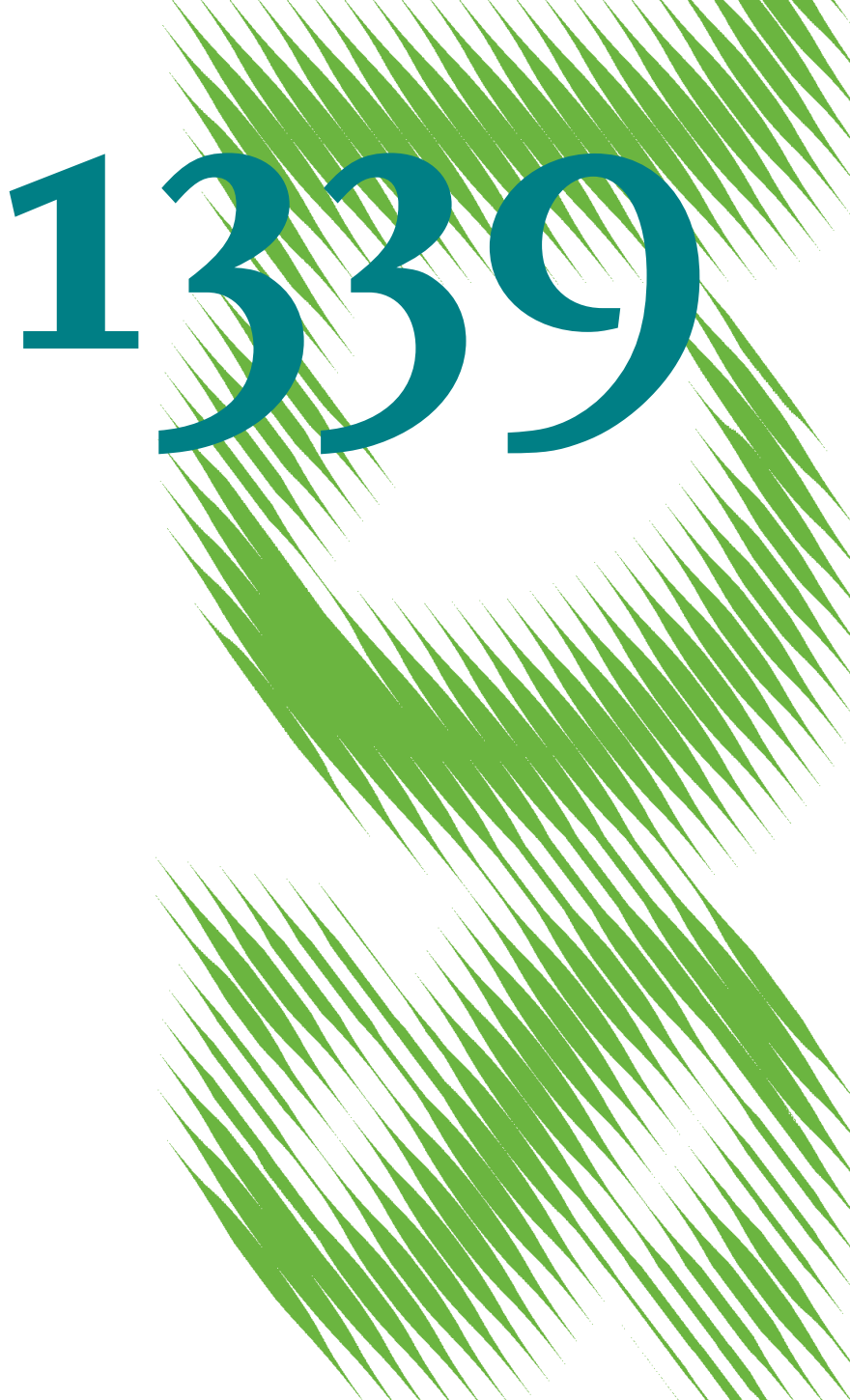

Fiscal Adjustments and

Business Cycle Synchronization 
Opinions expressed in this paper are those of the author(s) and do not necessarily reflect views of the institute.

IMPRESSUM

(C) DIW Berlin, 2013

DIW Berlin

German Institute for Economic Research

Mohrenstr. 58

10117 Berlin

Tel. $+49(30) 89789-0$

Fax +49 (30) $89789-200$

http://www.diw.de

ISSN print edition $1433-0210$

ISSN electronic edition 1619-4535

Papers can be downloaded free of charge from the DIW Berlin website:

http://www.diw.de/discussionpapers

Discussion Papers of DIW Berlin are indexed in RePEc and SSRN:

http://ideas.repec.org/s/diw/diwwpp.html

http://www.ssrn.com/link/DIW-Berlin-German-Inst-Econ-Res.html 


\title{
Fiscal Adjustments and \\ Business Cycle Synchronization
}

\section{Luca Agnello $^{*} \quad$ Guglielmo Maria Caporale $^{\dagger} \quad$ Ricardo M. Sousa $^{\$}$}

November 2013

\begin{abstract}
Using a panel of annual data for 20 countries we show that synchronized fiscal consolidation (stimulus) programmes in different countries make their business cycles more closely linked, especially in the case of fiscal adjustments lasting 2 or 3 years. We also find: (i) little evidence of decoupling when an inflation targeting regime is unilaterally adopted; (ii) an increase in business cycle synchronization when countries fix their exchange rates and become members of a monetary union; (iii) a positive effect of bilateral trade on the synchronization of business cycles.
\end{abstract}

JEL classification: C41, E62

Keywords: Fiscal consolidation, fiscal stimulus, business cycle synchronization

\footnotetext{
* University of Palermo, Faculty of Economics, Department of Economics, Business and Statistics, Viale delle Scienze, 90128 Palermo, Italy. Email: luca.agnello01@unipa.it.

${ }^{+}$Research Professor at DIW Berlin. Centre for Empirical Finance, Brunel University, London UB8 3PH, UK. Email: Guglielmo-Maria.Caporale@brunel.ac.uk.

\$University of Minho, Department of Economics and Economic Policies Research Unit (NIPE), Campus of Gualtar, 4710-057 - Braga, Portugal. E-mails: rjsousa@eeg.uminho.pt, rjsousa@alumni.Ise.ac.uk.
} 


\section{Introduction}

The financial crisis of 2008-9 forced many governments in developed countries to adopt expansionary fiscal policies with the aim of boosting the economy (Castro, 2010; Cimadomo et al., 2010; Agnello and Schuknecht, 2011; Agnello and Sousa, 2011, 2012; Cimadomo, 2012), and ultimately developed into a sovereign debt crisis. As concerns about long-term sustainability started mounting and government bond yields began hitting record levels, the shift from stimulus to austerity was not surprising: fiscal consolidation programmes were quickly designed and restrictive fiscal packages were put in place.

These events have generated among both policy-makers and academics a lively debate on the role of fiscal adjustments as stabilizing tools, as well as the apparent lower degree of synchronization of business cycle (Rafiq and Mallick, 2008; Mallick and Mohsin, 2007, 2010). Countries under financial stress and struggling to restore their public finances via consolidation measures appear to have no alternative but to pay the price of creating a recessionary environment (at least, in the short term). On the other hand, countries that managed to avoid fiscal austerity seem to be weathering better in terms of economic performance. This raises a number of questions on the impact of fiscal adjustments on business cycle synchronization. Specifically, do fiscal consolidation programmes lead to decoupling? What are the effects of fiscal stimulus episodes on the synchronization of business cycles? Are fiscal adjustments implemented by a single country more likely to result in de-synchronized business cycles (i.e. to reduce the correlation of the cyclical component of economic activity across countries) than programmes that are simultaneously adopted by different countries?

It is well known that countries may face asymmetric shocks (such as exchange rate or wage shocks) and that similar shocks (such as food price and oil price shocks) may have asymmetric effects. When these asymmetries are partially offset by fiscal adjustments, then fiscal consolidation/stimuli measures can lead to an increase in the synchronization of business cycles among countries. However, if fiscal policy procyclicality (Gavin and Perotti, 1997; Lane, 2003; Kaminsky et al., 2004; Aguiar et al., 2005) and changes in the institutional or the political background make sizeable fiscal adjustments unavoidable, then consolidation/stimulus programmes can be associated with a fall in business cycle synchronization. Thus, the nature of relationship between fiscal adjustments and business cycle synchronization is essentially an empirical issue. Its investigation with a suitable econometric framework is the aim of the present paper. 
Our analysis is related to various other studies on the determinants of business cycle synchronization. In particular, Artis (2008) shows that as the process of international trade deepens, regional business cycle affiliations are superseded by wider business cycle clubs. ${ }^{1}$ Devereux and Engel (1999, 2003) find that floating exchange rates protect the domestic economy from foreign monetary shocks (the so-called “insulation” effect). Baxter and Kouparitsas (2005) conclude that the degree of bilateral trade between a pair of countries has a robust effect on business cycle synchronization. Araújo and Oliveira Martins (2009a, 2009b) show that the deep fall in economic activity during the so-called "Great Recession" largely reflected the "Great Synchronization” of trade flow declines across countries. Kose et al. (2003, 2012) and Imbs (2006) emphasize that countries with closer financial ties tend to have more synchronized business cycles. Darvas and Szapáry (2000) do not find a significant impact of the exchange rate regime on capital flows across countries. Darvas and Szapáry (2008) examine business cycle synchronization in the new EU members of Central and Eastern Europe and the euro zone countries. They show that, despite the dramatic improvement in the correlation of the cyclical components of GDP, industrial production and exports among the new EU members, the degree of synchronization of private consumption with the euro zone countries remained low. Flood and Rose (2010) argue that business cycles in countries targeting inflation are only slightly synchronized with foreign ones.

We contribute to this literature by assessing the impact of fiscal adjustments on business cycle synchronization, an issue that, to the best of our knowledge, has not been investigated yet or for which somewhat related research is still at a seminal stage. Fatás and Mihov (2003) show that fiscal policy discretion leads to macroeconomic instability, while Kose et al. (2003) argue that fiscal policy amplifies country-specific idiosyncrasy, and Lane (2003) finds a positive link between output volatility and pro-cyclical fiscal policy. Fatás and Mihov (2006) conclude that budgetary restrictions reduce fiscal policy volatility and, therefore, fluctuations in economic activity. Darvas et al. (2005) highlight that the business cycles of countries with similar government budget positions move more closely. Thus, fiscal divergence i.e. deviations from a fiscally responsible behavior, creates idiosyncratic shocks and is associated with lower business cycles

\footnotetext{
${ }^{1}$ Artis and Zhang $(1997,1999)$ and Artis (2004) detect an 'European business cycle' since the early eighties. Artis et al. (2011) study the behaviour of the international business cycle across advanced and emerging market economies and find evidence of a secular increase in international business cycle synchronization within a group of European and a group of English-speaking economies.
} 
synchronization. More recently, Agnello and Sousa (2013a) stress that fiscal prudence i.e. a low and stable public deficit - is essential for achieving economic prosperity, while Agnello and Sousa (2013b) suggest that more political instability (in the form of a signal of an incoming government crisis) increases the likelihood of fiscal policy discretion. Agnello et al. (2013a) emphasize that fiscal variables (such as the budget deficit and the level of public debt) and economic factors (such as the degree of openness, the inflation rate, the interest rate and per capita GDP) are crucial for the fiscal consolidation process. Agnello et al. (2013b) find evidence that fiscal fatigue may compromise the implementation and successfulness of fiscal consolidation programmes. They conclude that chronic fiscal imbalances might lead to a vicious austerity cycle, while fiscal discipline is a means of achieving credible and shorter adjustments. Agnello et al. (2013a, 2013b) also suggest that there is a potential trade-off between short-term (crowding-in) and medium-term (crowding-out) effects of discretionary changes in fiscal policy, especially, during periods of crises.

In this paper we identify fiscal consolidation/stimulus programmes using a statistical framework based on Alesina and Ardagna (2010), and thus correct the primary surplus for year-to-year changes in the unemployment rate. Therefore, changes in fiscal variables should reflect policymakers' decisions to change tax rates and spending levels, once they are cyclically adjusted.

Using a panel of annual data for 20 countries, we show that fiscal consolidation (stimulus) episodes implemented by a single country (i.e. unilateral fiscal consolidation/stimulus programs) do not significantly impact on business cycle synchronization. By contrast, fiscal consolidation (stimulus) measures that are adopted by both countries (i.e. synchronized fiscal consolidation/stimulus programs) make their business cycles behave more closely, especially, in the case of episodes that last 2-3 years.

Our findings are robust across different techniques to compute the deviations of the business cycle from the trend, such as the Baxter-King band-pass filter and growth detrending. Moreover, they are qualitatively and quantitatively similar whether we focus on fiscal adjustments with an exact duration in years or use a more flexible approach that considers fiscal adjustments lasting at least a specific number of years over the 5year window periods.

Further, the results provide little evidence of decoupling when an inflation targeting regime is adopted unilaterally. However, there is an increase in business cycle 
synchronization when both countries fix their exchange rates and when countries become members of a monetary union. Finally, we uncover a positive effect of bilateral trade on business cycle synchronization.

The paper is organised as follows. Section 2 describes the econometric methodology and presents the data. Section 3 provides the empirical results. Section 4 concludes.

\section{Empirical Methodology}

In order to explore the empirical relationship between business cycle synchronization and fiscal adjustments, we use a panel dataset consisting of 20 countries and estimate the following model using a Fixed-Effects (FE) estimator: ${ }^{2}$

$$
\begin{aligned}
\rho_{i, j}^{\text {cycle }}= & \beta_{1} I T(1)_{i, j}+\beta_{2} I T(2)_{i, j}+\gamma_{1} \operatorname{Fix}(1)_{i, j}+\gamma_{2} \operatorname{Fix}(2)_{i, j}+ \\
& +\lambda_{1} \operatorname{MU}(1)_{i, j}+\lambda_{2} \operatorname{MU}(2)_{i, j}+\left\{\kappa_{1} \operatorname{Cons}(1)_{i, j}\right\}_{\tau=m}+\left\{\kappa_{2} \operatorname{Cons}(2)_{i, j}\right\}_{\tau=m}+\boldsymbol{X}_{i, j}+\varepsilon_{i, j}
\end{aligned}
$$

where $\rho_{\mathrm{i}, j}^{\text {cycle }}$ is the sample correlation coefficient (Pearson's coefficient) between real output in country $i$ and real output in $j$ over 5-year non-overlapping windows. Since we are interested in the business cycle deviations from the trend, we consider two alternative techniques for de-trending real output (GDP), namely: (i) the Baxter-King band-pass filter; and (ii) the fourth difference, i.e. the annual growth rate implied by the quarterly data. IT(1) and IT(2) are dummy variables that take the value of one if one or both countries are inflation targeters and zero, otherwise; Fix(1) and Fix(2) are dummy variables that take the value of one if one or both countries have a fixed exchange rate regime and zero, otherwise; $M U(1)$ and $M U(2)$ denote dummy variables that take the value of one if one or both countries are members of a monetary union; and Cons(1) and Cons(2) are dummy variables that take the value of one if one (unilateral adjustment) or both countries (synchronized adjustment) have implemented a fiscal consolidation programme for $m$ consecutive years within the 5-year non-overlapping window. Finally, $\boldsymbol{X}_{i, j}$ is a vector of control variables, which includes the degree of bilateral trade between countries $i$ and $j$ and the log distance between countries $i$ and $j$ (Baxter and Kouparitsas, 2005; Flood and Rose, 2010).

\footnotetext{
${ }^{2}$ The countries included in the sample are: Australia, Austria, Belgium, Canada, Denmark, Finland, France, Germany, Greece, Ireland, Italy, Japan, Netherlands, New Zealand, Norway, Portugal, Spain, Sweden, United Kingdom and United States.
} 
We also account for the effect of fiscal stimuli on business cycle synchronization. To that end, the dummy variables Cons(1) and Cons(2) are replaced with the dummy variables Stim(1) and Stim(2), which take the value of one if one or both countries have adopted fiscal stimuli packages for $\mathrm{m}$ consecutive years within the five-year non-overlapping window. Therefore, we run the following panel-data regression using a Fixed-Effects (FE) estimator:

$$
\begin{aligned}
\rho_{i, j}^{c y c l e}= & \beta_{1} I T(1)_{i, j}+\beta_{2} \operatorname{IT}(2)_{i, j}+\gamma_{1} \operatorname{Fix}(1)_{i, j}+\gamma_{2} \operatorname{Fix}(2)_{i, j}+ \\
& +\lambda_{1} \operatorname{MU}(1)_{i, j}+\lambda_{2} \operatorname{MU}(2)_{i, j}+\left\{\kappa_{1} \operatorname{Stim}(1)_{i, j}\right\}_{\tau=m}+\left\{\kappa_{2} \operatorname{Stim}(2)_{i, j}\right\}_{\tau=m}+\boldsymbol{X}_{i, j}+\varepsilon_{i, j}
\end{aligned}
$$

We identify fiscal consolidation programmes and fiscal stimulus episodes using a statistical approach based on the work of Alesina and Ardagna (2010). More specifically, a fiscal consolidation (stimulus) episode corresponds to a year in which the cyclically-adjusted primary balance improves (deteriorates) by at least 1.5\% of GDP.

Data on the seasonally adjusted GDP are obtained from the International Financial Statistics (IFS) and the World Economic Outlook (WEO) of the International Monetary Fund (IMF) and the Organization for Economic Co-Operation and Development (OECD). Information about inflation targeting regimes, fixed exchange rate regimes, monetary unions, the degree of bilateral trade and the distance between each pair of countries is taken from Flood and Rose (2010). Finally, fiscal consolidation (stimulus) episodes are identified using data from the OECD’s Economic Outlook.

\section{Empirical Results}

\subsection{Fiscal consolidation programmes}

We start our investigation of the impact of fiscal adjustments on business cycle synchronization by considering fiscal consolidation episodes that last exactly 1 year, 2 years, 3 years and 4 years over the 5 -year window period under analysis. ${ }^{3}$ For each experiment, we provide two sets of results: (i) one for the model without control variables; and (ii) another one where we add bilateral trade and the log distance to the set of regressors. Tables 1 and 2 summarize the empirical findings using a measure of business cycle synchronization based on the Baxter-King de-trending and growth detrending, respectively.

\footnotetext{
${ }^{3}$ Given the very small number of fiscal consolidation programmes that last exactly 5 years, we do not report the corresponding results.
} 
Given that the focus of our paper is on the relationship between fiscal adjustments and business cycle synchronization, we pay particular attention to the dummy variables, Cons(1) and Cons(2), which capture the implementation of unilateral and synchronized fiscal consolidations, respectively. Concerning unilateral fiscal consolidation episodes, overall the results do not point to a significant impact on business cycle synchronization. By contrast, when both countries implement fiscal consolidation measures (i.e. in the case of synchronized fiscal consolidations), the empirical findings suggest stronger business cycle synchronization. Indeed, the estimated coefficient for Cons(2) is statistically significant and large, especially for episodes lasting 2 or 3 years.

Turning to the effects of inflation targeting on business cycle synchronization, our results corroborate the findings of Flood and Rose (2010), who find little evidence of a significant impact. Specifically, there is little support for weakly synchronized business cycles resulting from only one country adopting inflation targeting (IT(1)), and most estimates associated with the case in which both countries adopt inflation targeting (IT(2)) are not statistically different from zero. The results are consistent across the various detrending techniques.

With regard to the exchange rate regime, the empirical findings clearly show that countries that fix exchange rates against each other (Fix(2)) have more synchronized business cycles. By contrast, when only one country (for each pair of countries considered) adopts a fixed exchange rate (Fix(1)), we do not find a significant effect on business cycle synchronization. This finding is close in spirit with the evidence presented by Araújo and Oliveira Martins (2009a, 2009b), who show that the sharp decline in economic activity observed during the most recent financial turmoil illustrates a uniquely synchronized global trade collapse. It is also consistent with the results of Agnello and Sousa (2013b), who show that countries with a less flexible exchange rate system are more insured against the uncertainty about the conduct of fiscal policy.

As for the effect of membership of a monetary union, the results are in accordance with the economic theory suggesting that a common monetary policy is associated with an increase in the degree of synchronization of business cycles. Interestingly, while both $M U(1)$ and $M U(2)$ are statistically significant, the coefficients associated with the latter are substantially larger i.e. business cycle synchronization is stronger when both countries are members of a monetary union. 
Finally, when looking at the control variables, we find that bilateral trade makes business cycles significantly more synchronized, while an increase in the distance among countries only weakly reduces business cycle synchronization.

\section{[ INSERT TABLE 1 HERE. ]}

\section{[ INSERT TABLE 2 HERE. ]}

A potential limitation of the previous estimates is the fact that only fiscal consolidation programmes with an exact duration in years are considered. For instance, within the 5-year window periods examined, the percentage of unilateral fiscal consolidation episodes that lasted exactly 1 and 3 years was $14.33 \%$ and $23.29 \%$. respectively; for synchronized fiscal consolidation episodes the corresponding percentages are $12.46 \%$ and $3.42 \%$ respectively. Therefore, we also take a more flexible approach considering fiscal consolidation programmes that last at least a specific number of years (i.e. 1 year, 2 years, 3 years and 4) over the 5-year window periods.

The results of this alternative procedure are summarized in Tables 3-4, again using both the Baxter-King and growth de-trending methods respectively to measure business cycle synchronization. Over the 5-year window periods considered, 78.55\% (25.09\%) of unilateral (synchronized) fiscal consolidation episodes lasted at least 1 year and $51.74 \%$ (6.05\%) had a length of at least 3 years.

The results corroborate the previous findings: fiscal consolidation programmes seem to have a positive effect on the synchronization of business cycles, especially when adopted by both countries. This impact is stronger when a low threshold is set for the minimum duration of the fiscal consolidation episode (say, at least 1 year or at least 2 years). Put differently, the higher the likelihood of a fiscal consolidation programme being implemented, the more synchronized the business cycles between two countries will be.

We also find: (i) weak evidence of decoupling when an inflation targeting regime is adopted unilaterally; (ii) an increase in business cycle synchronization when both countries fix the exchange rates vis-à-vis each other; (iii) a rise in the synchronization of business cycles when countries are members of a monetary union; and (iv) a positive effect of bilateral trade on business cycle synchronization.

[ INSERT TABLE 3 HERE. ] 


\section{[ INSERT TABLE 4 HERE. ]}

\subsection{Fiscal stimulus programmes}

We now examine the effects of fiscal stimulus programmes on business cycle synchronization. We consider unilateral adjustment episodes (Stim(1)) that last exactly 1 year, 2 years, 3 years and 4 years ${ }^{4}$ and synchronized adjustment episodes (Stim(2)) that last exactly 1 year and 2 years (i.e. the maximum duration of such type of synchronized events) over the 5-year window period. In our sample, the percentage of unilateral fiscal stimuli episodes lasting exactly 1 or 3 year is $53.39 \%$ and $4.63 \%$ respectively. The likelihood of synchronized fiscal stimulus episodes is much lower: the percentage of those lasting exactly 1 year and 2 years was $9.74 \%$ and $0.35 \%$ respectively.

We estimate our baseline model (2) with and without control variables (i.e. the bilateral trade and the log distance); Tables 5 and 6 summarize the main results using the two measures of business cycle synchronization. As in the case of fiscal consolidation programmes, the empirical findings suggest that unilateral fiscal stimulus episodes (Cons(1)) of short duration have a weakly significant impact on business cycle synchronization and lead to some decoupling, but no statistically significant effect is uncovered for longer programs. As for fiscal stimulus packages adopted by both countries, the results show that they increase significantly the synchronization of business cycles, especially in the case of programmes with longer duration (i.e. 2-year fiscal stimulus episodes).

Moreover, we find that when one country adopts inflation targeting (IT(1)), there is a fall in business cycle synchronization. By contrast, when both countries do so (IT(2)), the results do not support the existence of a statistically significant impact on business cycle synchronization. Further, it appears that while the adoption of a fixed exchange rate by a single country (Fix(1)) does not affect the synchronization of business cycles, when both countries fix their exchange rates (Fix(2)), business cycles become more synchronized.

Regarding the effects of membership of a monetary union, both $M U(1)$ and $M U(2)$ are found to be statistically significant and positively related with business cycle synchronization, with the effects being particularly large when both countries are members. Finally, the results confirm the role played by bilateral trade in increasing the correlation of the cyclical component of economic activity across countries, but

\footnotetext{
${ }^{4}$ There is no record of fiscal stimuli programmes with a 5-year length.
} 
geographical distance does not appear to have a significant impact on business cycle synchronization (Agnello and Sousa (2013a) also show that higher public deficit volatility is magnified in countries with a high degree of openness).

\section{[ INSERT TABLE 5 HERE. ] \\ [ INSERT TABLE 6 HERE. ]}

We also investigate the effect of fiscal stimulus programmes on business cycle synchronization using a more flexible approach that considers adjustment programmes with a minimum duration of 1 year and 2 years: 77.03\% (10.09\%) of unilateral (synchronized) fiscal stimulus episodes lasted at least 1 year and 26.51\% (0.35\%) had a length of at least 2 years over the 5-year window periods under consideration.

Tables 7 and 8 report the main findings based on the two measures of synchronization. As before, the impact of fiscal stimuli episodes on business cycle synchronization is statistically significant only when both countries implement such type of adjustments (Cons(2)) and, especially for fiscal stimulus programmes lasting at least 2 years. In addition, the results suggest that: (i) inflation targeting does not significantly affect the synchronization of business cycles; (ii) a significant and positive impact of the exchange rate regime on business cycle synchronization occurs when both countries fix their exchange rates; (iii) entry into a monetary union leads to an increase in the synchronization of business cycles; and (iv) bilateral trade increases the correlation of the cyclical component of economic activity across countries.

\section{[ INSERT TABLE 7 HERE. ] \\ [ INSERT TABLE 8 HERE. ]}

\section{Conclusions}

In this paper, we analyse the empirical relationship between fiscal adjustments and business cycle synchronization. Using annual data for a panel of 20 industrialized countries, we find that fiscal adjustments that are unilaterally implemented have no significant impact on business cycle synchronization. By contrast, fiscal consolidation (stimulus) measures that are adopted by countries at the same time (i.e. synchronized fiscal consolidation/stimulus programmes) lead to a closer co-movement of business cycles, especially when fiscal adjustments last for 2 or 3 years. We estimate that 
episodes of synchronized fiscal consolidation (stimulus) increase the correlation coefficient of the business cycle across countries by between 0.09 and 0.19 (0.09 and $0.69)$.

Our empirical findings also provide weak evidence that business cycles have become less synchronized across countries after the adoption of an inflation targeting regime. By contrast, fixing the exchange rate or membership of a monetary union leads to bigger co-movement of business cycles. We also find that while bilateral trade has a positive effect on business cycle synchronization, the distance between countries does not have a significant impact on the co-movement of the cyclical component of economic activity.

Finally, all these results are not sensitive to using different measures of business cycle synchronization or considering fiscal adjustments with an exact or a minimum duration in years. 


\section{References}

Agnello, L., and L. Schuknecht, 2011. Booms and busts in housing markets: determinants and implications. Journal of Housing Economics, 20(3), 171-190.

Agnello, A., and R. M. Sousa, 2011. Can fiscal stimulus boost economic recovery? Revue Économique, 62(6), 1045-1066.

Agnello, A., and R. M. Sousa, 2012. Fiscal policy and asset prices. Bulletin of Economic Research, 65(2), 154-177.

Agnello, A., and R. M. Sousa, 2013a. Political, institutional and economic factors underlying deficit volatility. Review of International Economics, 21(4), 719-732.

Agnello, A., and R. M. Sousa, 2013b. The determinants of the volatility of fiscal policy discretion. Fiscal Studies, forthcoming.

Agnello, A., Castro, V., and R. M. Sousa, 2013a. What determines the duration of a fiscal consolidation program? Journal of International Money and Finance, 37, 113134.

Agnello, A., Castro, V., and R. M. Sousa, 2013b. Is fiscal fatigue a threat to consolidation programmes? Environment \& Planning C: Government \& Policy, forthcoming.

Agnello, A., Furceri, D., and R. M. Sousa, 2013c. How best to measure discretionary fiscal policy? Assessing its impact on private spending. Economic Modelling, 34, 1524.

Agnello, A., Furceri, D., and R. M. Sousa, 2013d. Discretionary government consumption, private domestic demand, and crisis episodes. Open Economies Review, 24(1), 79-100.

Aguiar, M., Amador, M., and G. Gopinath, 2005. Efficient fiscal policy and amplification. National Bureau of Economic Research, NBER Working Paper No. 11490.

Alesina, A., and S. Ardagna, 2010. Large changes in fiscal policy: Taxes versus spending. In: Brown, J. R. (Ed.). Tax Policy and the Economy, Vol. 24. National Bureau of Economic Research, The University of Chicago Press.

Araújo, S., and J. Oliveira Martins, 2009a. The Great Synchronization: What do highfrequency statistics tell us about the trade collapse? VoxEU.org, 8 July.

Araújo, S., and J. Oliveira Martins, 2009b. The Great Synchronization: tracking the trade collapse with high-frequency data. VoxEU.org, 27 November. 
Artis, M., 2004. Is there a European business cycle? In: Siebert, H. (Ed.), Macroeconomic Policies in the World Economy, Berlin, Springer.

Artis, M., 2008. Europeanization or globalization? What do business cycle affiliations say? In: Shlomowitz, R. (Ed.), Flinders Essays in Economics and Economic History, Adelaide, Wakefield Press.

Artis, M., Chouliarakis, G., and P. K. G. Harischandra, 2011. Business cycle synchronization since 1880. The Manchester School, 79(2), 173-207.

Artis, M., and W. Zhang, 1997. International business cycles and the ERM: Is there a European business cycle? International Journal of Finance and Economics, 2, 1-16.

Artis, M., and W. Zhang, 1999. Further evidence of the international business cycle and the ERM: Is there a European business cycle? Oxford Economic Papers, 51, 120-132.

Baxter, M., and M. A. Kouparitsas, 2005. Determinants of business cycle comovement: a robust analysis. Journal of Monetary Economics, 52(1), 113-157.

Castro, V., 2010. The duration of economic expansions and recessions: more than duration dependence. Journal of Macroeconomics, 32, 347-365.

Cimadomo, J., 2012. Fiscal policy in real time. Scandinavian Journal of Economics, 114(2), 440-465.

Cimadomo, J., Kirchner M., and S. Hauptmeier, 2010. Transmission of government spending shocks in the euro area: Time variation and driving forces. European Central Bank, ECB Working Paper No. 1219.

Darvas, Z., and G. Szapáry, 2000. Financial contagion in five small open economies: Does the exchange rate regime really matter? International Finance, 3(1), 25-51.

Darvas, Z., and G. Szapáry, 2008. Business cycle synchronization in the enlarged EU. Open Economies Review, 19(1), 1-19.

Darvas, Z., Rose, A. K., and G. Szapáry, 2005. Fiscal divergence and business cycle synchronization: Irresponsability is idiosynchratic. NBER International Seminar on Macroeconomics. MIT Press.

Devereux, M. B., and C. Engel, 1999. The optimal choice of exchange-rate regime. National Bureau of Economic Research, NBER Working Paper No. 6992.

Devereux, M. B., and C. Engel, 2003. Monetary policy in the open economy revisited: price setting and exchange rate flexibility. Review of Economic Studies, 70, 765-784.

Fatás, A., and I. Mihov, 2003. The case for restricting fiscal policy discretion. Quarterly Journal of Economics, 118(4), 1419-1447. 
Fatás, A., and I. Mihov, 2006. The macroeconomic effects of fiscal rules in the US States. Journal of Public Economics, 90(1-2), 101-117.

Flood, R. P., and A. K. Rose, 2010. Inflation targeting and business cycle synchronization. Journal of International Money and Finance, 29(4), 704-727.

Gavin, M., and R. Perotti, 1997. Fiscal policy in Latin America. NBER Macroeconomics Annual, 12, 11-61.

Imbs, J., 2006. The real effects of financial integration. Journal of International Economics, 68(2), 296-324.

Kaminsky, G., Reinhart, C., and C. Vegh, 2004. When it rains, it pours. NBER Macroeconomics Annual, 19, 11-53.

Kose, A., Otrok, C. and C. Whiteman, 2003. International business cycles: World, region, and country-specific factors. American Economic Review, 93, 1216-1239.

Kose, M. A., Otrok, C., and E. Prasad, 2012. Global business cycles: Convergence or decoupling? International Economic Review, 53(2), 511-538.

Lane, P. R., 2003. The cyclical behaviour of fiscal policy: evidence from the OECD. Journal of Public Economics, 87, 2661-2675.

Mallick, S. K., and M. Mohsin, 2007. On the effects of inflation shocks in a small open economy. Australian Economic Review, 40(3), 253-266.

Mallick, S.K., Mohsin, M., 2010. On the real effects of inflation in open economies: theory and empirics. Empirical Economics, 39(3), 643-673.

Rafiq, M.S., Mallick, S.K., 2008. The effect of monetary policy on output in EMU3: a sign restriction approach. Journal of Macroeconomics, 30, 1756-1791. 
Table 1: Fiscal consolidation and business cycle synchronization - Baxter-King detrending.

\begin{tabular}{|c|c|c|c|c|c|c|c|c|}
\hline \multirow{3}{*}{$\bar{~} \mathrm{IT(1)}$} & \multicolumn{8}{|c|}{ duration (in years) of fiscal consolidation episodes within the 5 -year window periods } \\
\hline & \multicolumn{2}{|c|}{1 year } & \multicolumn{2}{|c|}{2 years } & \multicolumn{2}{|c|}{3 years } & \multicolumn{2}{|c|}{4 years } \\
\hline & $-0.1622^{\star}$ & -0.1178 & $-0.1564^{*}$ & -0.1045 & $-0.1677^{\star}$ & -0.1199 & $-0.1565^{\star}$ & -0.1116 \\
\hline & [0.0688] & [0.0649] & {$[0.0725]$} & {$[0.0670]$} & [0.0733] & [0.0670] & [0.0709] & [0.0669] \\
\hline \multirow[t]{2}{*}{ IT(2) } & 0.1369 & 0.158 & 0.1623 & 0.1827 & 0.1139 & 0.1366 & 0.1431 & 0.1589 \\
\hline & [0.1664] & [0.1751] & {$[0.1386]$} & [0.1511] & [0.1242] & [0.1443] & [0.1385] & [0.1526] \\
\hline \multirow[t]{2}{*}{$\operatorname{Fix}(1)$} & 0.0471 & 0.013 & 0.0501 & 0.0111 & 0.0508 & 0.015 & 0.0513 & 0.0214 \\
\hline & [0.0344] & {$[0.0521]$} & {$[0.0407]$} & [0.0614] & {$[0.0347]$} & [0.0507] & [0.0352] & [0.0508] \\
\hline \multirow[t]{2}{*}{$\operatorname{Fix}(2)$} & $0.2626^{\star \star}$ & $0.2324^{\star * *}$ & $0.2636^{\star \star}$ & $0.2326^{\star \star \star}$ & $0.2642^{\star \star}$ & $0.2218^{\star \star}$ & $0.2564^{\star \star}$ & $0.2313^{\star *}$ \\
\hline & [0.0616] & {$[0.0470]$} & {$[0.0619]$} & [0.0479] & [0.0622] & [0.0510] & [0.0654] & [0.0549] \\
\hline \multirow[t]{2}{*}{$\mathrm{MU}(1)$} & $0.1351^{\star \star}$ & $0.1561^{*}$ & $0.1818^{\star \star \star}$ & $0.2004^{\star \star \star}$ & $0.1506^{\star \star \star}$ & $0.1655^{\star \star}$ & $0.1441^{* * *}$ & $0.1606^{\star *}$ \\
\hline & {$[0.0474]$} & [0.0568] & {$[0.0270]$} & [0.0435] & {$[0.0250]$} & [0.0389] & [0.0298] & [0.0425] \\
\hline \multirow[t]{2}{*}{$\mathrm{MU}(2)$} & $0.2652^{\star * \star}$ & 0.1879 ** & $0.2880^{\star \star \star}$ & $0.2046^{\star \star}$ & $0.2710^{\star \star \star}$ & $0.1870^{\star *}$ & $0.2748^{\star \star \star}$ & $0.1948^{\star \star}$ \\
\hline & {$[0.0147]$} & {$[0.0635]$} & {$[0.0160]$} & [0.0622] & {$[0.0170]$} & {$[0.0604]$} & [0.0141] & {$[0.0587]$} \\
\hline \multirow[t]{2}{*}{ Cons(1) } & -0.0164 & -0.0373 & $0.0428^{\star *}$ & $0.0797^{\star \star *}$ & 0.0141 & 0.0126 & 0.0784 & 0.0632 \\
\hline & [0.0624] & {$[0.0444]$} & [0.0153] & [0.0102] & {$[0.0321]$} & [0.0177] & [0.0582] & [0.0635] \\
\hline \multirow[t]{2}{*}{ Cons(2) } & 0.1265 & 0.1014 & $0.0933^{\star}$ & $0.0937^{\star}$ & $0.1928^{* * *}$ & $0.1492^{*}$ & $0.1854^{\star * *}$ & $0.1412^{\star * *}$ \\
\hline & [0.0861] & {$[0.0757]$} & [0.0362] & [0.0355] & [0.0382] & [0.0583] & [0.0178] & {$[0.0156]$} \\
\hline \multirow[t]{2}{*}{ Bilateral trade } & & $4.5902^{\star *}$ & & $4.6573^{\star \star}$ & & $4.4656^{\star *}$ & & $4.6666^{\star *}$ \\
\hline & & [1.0684] & & [1.1089] & & [1.0076] & & [1.1754] \\
\hline \multirow[t]{2}{*}{ Distance } & & -0.0587 & & -0.0631 & & -0.0614 & & -0.0583 \\
\hline & & [0.0443] & & [0.0448] & & [0.0464] & & [0.0462] \\
\hline \multirow[t]{2}{*}{ Constant } & $0.2288^{\star \star \star}$ & 0.6425 & $0.2182^{\star \star \star}$ & 0.6509 & $0.2334^{\star \star \star}$ & 0.6655 & $0.2277^{\star \star \star}$ & 0.6348 \\
\hline & {$[0.0258]$} & {$[0.3649]$} & {$[0.0274]$} & {$[0.3804]$} & {$[0.0315]$} & [0.3891] & {$[0.0231]$} & {$[0.3817]$} \\
\hline Observations & 950 & 874 & 950 & 874 & 950 & 874 & 950 & 874 \\
\hline R-squared & 0.07 & 0.11 & 0.07 & 0.11 & 0.07 & 0.1 & 0.07 & 0.1 \\
\hline
\end{tabular}

Robust standard errors in brackets. * significant at 10\%; ** significant at 5\%; *** significant at $1 \%$. 
Table 2: Fiscal consolidation and business cycle synchronization - Growth detrending. duration (in years) of fiscal consolidation episodes within the 5 -year window periods

\begin{tabular}{|c|c|c|c|c|c|c|c|c|}
\hline \multirow[b]{2}{*}{$\mathrm{IT}(1)$} & \multicolumn{2}{|c|}{1 year } & \multicolumn{2}{|c|}{2 years } & \multicolumn{2}{|c|}{3 years } & \multicolumn{2}{|c|}{4 years } \\
\hline & -0.016 & 0.0163 & -0.0094 & 0.0295 & -0.0183 & 0.0177 & -0.0082 & 0.0233 \\
\hline & [0.0605] & [0.0531] & [0.0606] & [0.0536] & [0.0594] & [0.0516] & {$[0.0620]$} & [0.0548] \\
\hline \multirow[t]{2}{*}{$\mathrm{IT}(2)$} & 0.0793 & 0.098 & $0.1068^{*}$ & $0.1239 *$ & 0.0614 & 0.0838 & 0.0856 & 0.0998 \\
\hline & [0.0745] & [0.0785] & [0.0468] & [0.0562] & [0.0453] & [0.0600] & {$[0.0475]$} & [0.0579] \\
\hline \multirow[t]{2}{*}{$\operatorname{Fix}(1)$} & 0.0129 & -0.0137 & 0.0156 & -0.0165 & 0.0176 & -0.011 & 0.0179 & -0.0052 \\
\hline & [0.0183] & [0.0179] & [0.0199] & {$[0.0217]$} & [0.0175] & [0.0173] & [0.0174] & [0.0164] \\
\hline \multirow[t]{2}{*}{$\operatorname{Fix}(2)$} & $0.1547^{\star \star \star}$ & $0.1224^{\star \star *}$ & $0.1559 * \star \star$ & $0.1233^{\star \star * \star}$ & $0.1553^{\star \star \star *}$ & $0.1123^{\star \star}$ & $0.1487^{\star \star \star}$ & $0.1197^{\star *}$ \\
\hline & [0.0296] & [0.0243] & [0.0299] & [0.0245] & [0.0326] & [0.0342] & [0.0356] & [0.0347] \\
\hline \multirow[t]{2}{*}{$\mathrm{MU}(1)$} & 0.0458 & $0.0669^{*}$ & $0.0957^{\star \star \star}$ & $0.1126^{\star \star *}$ & $0.0607^{\star \star \star}$ & $0.0776^{\star * *}$ & $0.0510^{\star \star *}$ & $0.0692^{\star * *}$ \\
\hline & [0.0239] & [0.0279] & [0.0150] & [0.0242] & [0.0131] & [0.0186] & [0.0109] & [0.0164] \\
\hline \multirow[t]{2}{*}{$\mathrm{MU}(2)$} & $0.0764^{* *}$ & 0.009 & $0.0974^{* * *}$ & 0.0238 & 0.0819 *** & 0.0095 & $0.0831^{* * *}$ & 0.0133 \\
\hline & {$[0.0236]$} & [0.0625] & [0.0183] & [0.0594] & [0.0181] & [0.0592] & [0.0166] & [0.0583] \\
\hline \multirow[t]{2}{*}{ Cons(1) } & -0.0333 & -0.0499 & $0.0537^{\star \star *}$ & $0.0847^{\star \star \star *}$ & 0.0163 & 0.0185 & $0.0912^{*}$ & 0.0681 \\
\hline & [0.0613] & [0.0469] & [0.0051] & [0.0098] & [0.0255] & [0.0296] & {$[0.0450]$} & [0.0449] \\
\hline \multirow[t]{2}{*}{ Cons(2) } & 0.1234 & 0.0954 & $0.1218^{\star \star}$ & $0.1206^{\star \star}$ & $0.1448^{\star \star}$ & 0.0888 & $0.1278^{\star \star \star}$ & $0.0777^{\star}$ \\
\hline & [0.0762] & {$[0.0734]$} & [0.0472] & [0.0457] & [0.0502] & {$[0.0466]$} & [0.0088] & [0.0323] \\
\hline \multirow[t]{2}{*}{ Bilateral trade } & & $4.3007^{\star \star}$ & & $4.3027^{\star \star}$ & & $4.2843^{\star \star \star}$ & & $4.3794^{\star \star}$ \\
\hline & & [1.0970] & & [1.1664] & & [1.0561] & & [1.1357] \\
\hline \multirow[t]{2}{*}{ Distance } & & -0.0467 & & -0.0511 & & -0.0484 & & -0.0461 \\
\hline & & [0.0407] & & [0.0415] & & {$[0.0436]$} & & [0.0430] \\
\hline \multirow[t]{2}{*}{ Constant } & $0.2830^{\star \star \star}$ & 0.6063 & $0.2647^{* \star *}$ & 0.6096 & $0.2846^{\star \star \star}$ & 0.6168 & $0.2786^{\star \star \star}$ & 0.5952 \\
\hline & {$[0.0179]$} & [0.3188] & [0.0179] & {$[0.3400]$} & {$[0.0147]$} & [0.3463] & [0.0158] & [0.3443] \\
\hline Observations & 960 & 884 & 960 & 884 & 960 & 884 & 960 & 884 \\
\hline R-squared & 0.04 & 0.09 & 0.03 & 0.1 & 0.02 & 0.08 & 0.03 & 0.09 \\
\hline
\end{tabular}

Robust standard errors in brackets. * significant at $10 \%$; ${ }^{* *}$ significant at $5 \%$; ${ }^{* \star *}$ significant at $1 \%$. 
Table 3: Fiscal consolidation and business cycle synchronization - Baxter-King detrending (minimum duration).

\begin{tabular}{|c|c|c|c|c|c|c|c|c|}
\hline \multirow[b]{3}{*}{$\mathrm{IT}(1)$} & \multicolumn{8}{|c|}{ minimum duration of fiscal consolidation episodes within the 5 -year window periods } \\
\hline & \multicolumn{2}{|c|}{ at least 1 year } & \multicolumn{2}{|c|}{ at least 2 years } & \multicolumn{2}{|c|}{ at least 3 years } & \multicolumn{2}{|c|}{ at least 4 years } \\
\hline & $-0.1856^{*}$ & -0.1369 & -0.1775 & -0.1263 & $-0.1832^{\star}$ & -0.1301 & $-0.1816^{*}$ & -0.1292 \\
\hline & {$[0.0776]$} & [0.0705] & [0.0869] & {$[0.0794]$} & [0.0810] & [0.0715] & {$[0.0761]$} & [0.0664] \\
\hline \multirow[t]{2}{*}{ IT(2) } & 0.1111 & 0.1295 & 0.1374 & 0.1535 & 0.1062 & 0.1333 & 0.1425 & 0.162 \\
\hline & {$[0.1430]$} & [0.1601] & [0.1140] & {$[0.1342]$} & [0.1179] & [0.1429] & [0.1349] & [0.1532] \\
\hline \multirow[t]{2}{*}{$\operatorname{Fix}(1)$} & 0.0347 & -0.0003 & 0.0388 & 0.0000 & 0.0431 & 0.01 & 0.0415 & 0.0131 \\
\hline & [0.0369] & [0.0550] & [0.0372] & {$[0.0551]$} & {$[0.0316]$} & {$[0.0486]$} & [0.0365] & {$[0.0527]$} \\
\hline \multirow[t]{2}{*}{$\operatorname{Fix}(2)$} & $0.2639 \star \star$ & $0.2415^{\star \star \star}$ & $0.2651^{\star \star}$ & $0.2332^{\star \star}$ & $0.2610^{\star \star}$ & $0.2246^{\star \star}$ & $0.2595^{\star \star}$ & $0.2276^{\star \star}$ \\
\hline & [0.0591] & [0.0465] & {$[0.0627]$} & {$[0.0529]$} & {$[0.0654]$} & [0.0562] & {$[0.0656]$} & [0.0533] \\
\hline \multirow[t]{2}{*}{$\mathrm{MU}(1)$} & $0.1405^{\star \star}$ & $0.1483^{\star \star}$ & 0.1779 *** & $0.1802^{\star *}$ & $0.1414^{\star \star \star}$ & $0.1566^{\star \star}$ & $0.1318^{\star * *}$ & $0.1532^{\star \star}$ \\
\hline & {$[0.0306]$} & [0.0468] & [0.0235] & [0.0392] & {$[0.0205]$} & [0.0364] & [0.0232] & [0.0364] \\
\hline \multirow[t]{2}{*}{$\mathrm{MU}(2)$} & $0.2575^{\star \star \star}$ & $0.1813^{\star \star}$ & $0.2819 * \star \star$ & $0.1934^{\star \star}$ & $0.2640 * \star *$ & $0.1837^{\star *}$ & $0.2618^{\star \star *}$ & $0.1848^{\star \star}$ \\
\hline & {$[0.0166]$} & [0.0604] & [0.0223] & {$[0.0604]$} & [0.0191] & [0.0587] & [0.0154] & [0.0571] \\
\hline \multirow[t]{2}{*}{ Cons(1) } & $0.1156^{*}$ & $0.1053^{*}$ & $0.1060^{* *}$ & $0.1091^{\star \star}$ & $0.0751^{\star}$ & $0.0565^{\star}$ & $0.1107^{\star * *}$ & $0.0818^{\star \star}$ \\
\hline & [0.0418] & [0.0411] & [0.0374] & {$[0.0272]$} & {$[0.0277]$} & [0.0219] & [0.0163] & [0.0218] \\
\hline \multirow[t]{2}{*}{ Cons(2) } & $0.1432^{\star \star}$ & $0.1154^{\star \star}$ & $0.1047^{\star *}$ & $0.0757^{\star}$ & $0.1406^{\star \star \star}$ & $0.0911^{\star *}$ & $0.0396^{\star}$ & -0.0178 \\
\hline & {$[0.0378]$} & {$[0.0388]$} & [0.0303] & [0.0322] & [0.0195] & [0.0296] & {$[0.0176]$} & [0.0294] \\
\hline \multirow[t]{2}{*}{ B-K bilateral trade } & & $3.4746^{\star \star}$ & & $3.6374^{\star *}$ & & $4.0928^{\star \star}$ & & $4.5064^{\star \star}$ \\
\hline & & [1.2429] & & [1.0985] & & [1.0543] & & [1.1399] \\
\hline \multirow[t]{2}{*}{ Log distance } & & -0.0610 & & -0.0678 & & -0.0623 & & -0.0593 \\
\hline & & [0.0467] & & [0.0439] & & [0.0466] & & {$[0.0471]$} \\
\hline \multirow[t]{2}{*}{ Constant } & $0.1221^{*}$ & 0.5741 & $0.1573^{\star \star}$ & 0.6478 & $0.2051^{\star \star \star}$ & 0.6558 & $0.2199 * * *$ & 0.6401 \\
\hline & [0.0555] & {$[0.4094]$} & [0.0485] & [0.3848] & [0.0331] & [0.3936] & {$[0.0237]$} & [0.3924] \\
\hline Observations & 950 & 874 & 950 & 874 & 950 & 874 & 950 & 874 \\
\hline R-squared & 0.09 & 0.12 & 0.08 & 0.12 & 0.07 & 0.11 & 0.07 & 0.11 \\
\hline
\end{tabular}

Robust standard errors in brackets. ${ }^{*}$ significant at $10 \% ;{ }^{* *}$ significant at $5 \% ;{ }^{* \star \star}$ significant at $1 \%$. 
Table 4: Fiscal consolidation and business cycle synchronization - Growth detrending (minimum duration). minimum duration of fiscal consolidation episodes within the 5 -year window periods

\begin{tabular}{|c|c|c|c|c|c|c|c|c|}
\hline \multirow{3}{*}{$\bar{~}$} & & & & & & & & \\
\hline & \multicolumn{2}{|c|}{ at least 1 year } & \multicolumn{2}{|c|}{ at least 2 years } & \multicolumn{2}{|c|}{ at least 3 years } & \multicolumn{2}{|c|}{ at least 4 years } \\
\hline & -0.0371 & -0.0005 & -0.0291 & 0.0092 & -0.032 & 0.0087 & -0.0343 & 0.0062 \\
\hline & [0.0643] & [0.0552] & [0.0696] & [0.0617] & [0.0636] & [0.0531] & [0.0558] & [0.0465] \\
\hline \multirow[t]{2}{*}{$\mathrm{IT}(2)$} & 0.0509 & 0.0684 & $0.0777^{\star}$ & 0.0923 & 0.0576 & 0.0853 & 0.0859 & 0.1035 \\
\hline & [0.0557] & [0.0675] & [0.0303] & [0.0462] & [0.0432] & [0.0624] & [0.0450] & [0.0591] \\
\hline \multirow[t]{2}{*}{$\operatorname{Fix}(1)$} & 0.0013 & -0.0262 & 0.0045 & -0.0268 & 0.0104 & -0.0156 & 0.008 & -0.0127 \\
\hline & [0.0225] & [0.0253] & [0.0250] & [0.0283] & [0.0213] & [0.0202] & [0.0188] & {$[0.0175]$} \\
\hline \multirow[t]{2}{*}{ Fix(2) } & $0.1555^{\star \star \star}$ & $0.1307^{\star * \star}$ & $0.1570^{\star * *}$ & $0.1237^{\star * *}$ & $0.1523^{\star \star \star}$ & $0.1129^{* *}$ & $0.1514^{\star * *}$ & $0.1162^{\star \star}$ \\
\hline & [0.0253] & [0.0214] & [0.0296] & [0.0244] & [0.0339] & [0.0351] & [0.0346] & [0.0342] \\
\hline \multirow[t]{2}{*}{$\mathrm{MU}(1)$} & $0.0469 * *$ & $0.0561^{\star *}$ & $0.0826^{\star *}$ & $0.0848^{\star \star}$ & $0.0515^{\star \star}$ & $0.0686^{\star *}$ & $0.0397^{\star *}$ & $0.0629^{* * *}$ \\
\hline & [0.0130] & [0.0195] & [0.0209] & {$[0.0254]$} & [0.0161] & [0.0178] & [0.0123] & [0.0142] \\
\hline \multirow[t]{2}{*}{$\mathrm{MU}(2)$} & $0.0627^{* \star}$ & -0.0015 & $0.0867^{\star \star \star *}$ & 0.0098 & $0.0745^{\star \star \star}$ & 0.0052 & $0.0692^{\star \star \star}$ & 0.0036 \\
\hline & {$[0.0166]$} & [0.0589] & {$[0.0210]$} & {$[0.0563]$} & {$[0.0166]$} & [0.0562] & {$[0.0124]$} & [0.0535] \\
\hline \multirow[t]{2}{*}{ Cons(1) } & $0.1218^{\star \star \star}$ & $0.1092^{\star \star \star}$ & $0.1203^{* \star *}$ & $0.1190^{\star * *}$ & $0.0850^{\star *}$ & $0.0658^{\star}$ & $0.1191^{\star *}$ & $0.0836^{*}$ \\
\hline & [0.0163] & [0.0200] & [0.0255] & [0.0225] & [0.0254] & [0.0267] & [0.0331] & {$[0.0376]$} \\
\hline \multirow[t]{2}{*}{ Cons(2) } & $0.1353^{\star \star *}$ & $0.1043^{\star *}$ & $0.0905^{*}$ & 0.0605 & $0.0836^{\star \star *}$ & 0.0267 & -0.0093 & -0.0612 \\
\hline & {$[0.0298]$} & {$[0.0361]$} & {$[0.0354]$} & {$[0.0339]$} & [0.0193] & [0.0150] & {$[0.0210]$} & [0.0338] \\
\hline \multirow[t]{2}{*}{$\mathrm{B}-\mathrm{K}$ bilateral trade } & & $3.2537^{\star \star}$ & & $3.3719^{* *}$ & & $3.9137^{* *}$ & & $4.2571^{\star *}$ \\
\hline & & [1.1406] & & [1.0302] & & [1.0764] & & [1.1779] \\
\hline \multirow[t]{2}{*}{ Log distance } & & -0.0484 & & -0.0552 & & -0.0498 & & -0.0469 \\
\hline & & {$[0.0437]$} & & [0.0413] & & [0.0432] & & {$[0.0436]$} \\
\hline \multirow[t]{2}{*}{ Constant } & $0.1715^{\star \star \star}$ & 0.5305 & 0.2016 *** & 0.6004 & 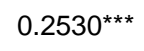 & 0.6086 & $0.2708^{\star \star *}$ & 0.5978 \\
\hline & {$[0.0321]$} & [0.3555] & {$[0.0319]$} & {$[0.3437]$} & [0.0185] & [0.3470] & [0.0170] & [0.3475] \\
\hline Observations & 960 & 884 & 960 & 884 & 960 & 884 & 960 & 884 \\
\hline R-squared & 0.07 & 0.12 & 0.06 & 0.11 & 0.04 & 0.09 & 0.04 & 0.09 \\
\hline
\end{tabular}

Robust standard errors in brackets. * significant at $10 \%$; ** significant at $5 \%$; *** significant at $1 \%$. 
Table 5: Fiscal stimuli and business cycle synchronization - Baxter-King detrending. duration (in years) of fiscal stimuli episodes within the 5 -year window periods

\begin{tabular}{|c|c|c|c|c|c|c|c|c|}
\hline \multirow{3}{*}{ } & \multirow{2}{*}{\multicolumn{2}{|c|}{1 year }} & \multirow{2}{*}{\multicolumn{2}{|c|}{2 years }} & \multirow{2}{*}{\multicolumn{2}{|c|}{3 years }} & \multirow{2}{*}{\multicolumn{2}{|c|}{4 years }} \\
\hline & & & & & & & & \\
\hline & $-0.1701^{\star \star}$ & $-0.1291^{*}$ & $-0.1549^{\star}$ & -0.1052 & $-0.1562^{\star}$ & -0.1109 & $-0.1589^{\star}$ & -0.1136 \\
\hline & [0.0612] & {$[0.0530]$} & [0.0624] & {$[0.0570]$} & [0.0688] & {$[0.0638]$} & [0.0691] & [0.0634] \\
\hline \multirow[t]{2}{*}{$\mathrm{IT}(2)$} & 0.1357 & 0.1523 & 0.1422 & 0.1566 & 0.1456 & 0.1621 & 0.1459 & 0.1623 \\
\hline & [0.1478] & [0.1595] & [0.1424] & [0.1566] & [0.1463] & [0.1597] & [0.1465] & [0.1597] \\
\hline \multirow[t]{2}{*}{$\operatorname{Fix}(1)$} & 0.0538 & 0.0232 & 0.0514 & 0.0121 & 0.0544 & 0.0187 & 0.0535 & 0.0186 \\
\hline & [0.0416] & [0.0592] & [0.0316] & [0.0494] & [0.0364] & [0.0545] & [0.0368] & [0.0540] \\
\hline \multirow[t]{2}{*}{$\operatorname{Fix}(2)$} & $0.2590^{\star *}$ & $0.2264^{\star \star \star}$ & $0.2779^{\star \star}$ & $0.2445^{\star \star}$ & $0.2602^{\star \star}$ & $0.2228^{\star \star}$ & $0.2616^{\star \star}$ & $0.2250^{\star *}$ \\
\hline & [0.0584] & [0.0487] & [0.0693] & [0.0609] & [0.0618] & [0.0506] & [0.0637] & [0.0513] \\
\hline \multirow[t]{2}{*}{$\mathrm{MU}(1)$} & $0.1422^{\star *}$ & $0.1615^{\star \star}$ & $0.1494^{\star \star \star}$ & $0.1581^{\star \star}$ & $0.1590^{* * *}$ & $0.1745^{\star \star}$ & $0.1584^{\star * *}$ & $0.1739^{\star *}$ \\
\hline & [0.0368] & [0.0449] & [0.0300] & [0.0445] & [0.0295] & [0.0418] & [0.0294] & [0.0416] \\
\hline \multirow[t]{2}{*}{$\mathrm{MU}(2)$} & $0.2549^{\star \star \star}$ & $0.1776^{\star \star}$ & $0.2617^{\star \star \star}$ & $0.1701^{\star \star}$ & $0.2774^{\star \star *}$ & $0.1937^{\star \star}$ & $0.2764^{\star \star \star}$ & $0.1935^{\star *}$ \\
\hline & {$[0.0178]$} & [0.0582] & [0.0073] & [0.0567] & {$[0.0126]$} & [0.0599] & [0.0123] & [0.0597] \\
\hline \multirow[t]{2}{*}{ Cons(1) } & 0.0102 & 0.0296 & -0.1443 & $-0.1546^{\star}$ & 0.0552 & 0.052 & $0.2260^{\star \star \star}$ & $0.1892^{*}$ \\
\hline & [0.0448] & [0.0346] & [0.0952] & [0.0682] & [0.0631] & [0.0486] & [0.0231] & [0.0748] \\
\hline \multirow[t]{2}{*}{ Cons(2) } & 0.1593 & 0.1346 & $0.2772^{\star \star \star}$ & $0.3254^{\star \star \star}$ & - & - & - & - \\
\hline & {$[0.0789]$} & [0.0649] & [0.0086] & [0.0118] & - & - & - & - \\
\hline \multirow[t]{2}{*}{ Bilateral trade } & & $4.9900^{\star \star}$ & & $4.3237^{\star \star \star}$ & & $4.8555^{\star \star}$ & & $4.8435^{\star \star}$ \\
\hline & & [1.1710] & & [0.9277] & & [1.1277] & & [1.1046] \\
\hline \multirow[t]{2}{*}{ Distance } & & -0.0522 & & -0.0677 & & -0.0589 & & -0.0584 \\
\hline & & {$[0.0451]$} & & [0.0472] & & {$[0.0466]$} & & [0.0468] \\
\hline \multirow[t]{2}{*}{ Constant } & $0.2245^{\star \star \star}$ & 0.5721 & $0.2648^{\star \star \star}$ & 0.7483 & $0.2335^{\star \star \star}$ & 0.6416 & $0.2346^{\star \star \star}$ & 0.6394 \\
\hline & {$[0.0337]$} & [0.3805] & [0.0123] & {$[0.3841]$} & {$[0.0206]$} & [0.3868] & {$[0.0219]$} & [0.3901] \\
\hline Observations & 950 & 874 & 950 & 874 & 950 & 874 & 950 & 874 \\
\hline R-squared & 0.07 & 0.11 & 0.08 & 0.12 & 0.06 & 0.10 & 0.07 & 0.10 \\
\hline
\end{tabular}

Robust standard errors in brackets. * significant at 10\%; ** significant at $5 \%$; ${ }^{* \star}$ significant at $1 \%$. 
Table 6: Fiscal stimuli and business cycle synchronization - Growth detrending. duration (in years) of fiscal stimuli episodes within the 5 -year window periods

\begin{tabular}{|c|c|c|c|c|c|c|c|c|}
\hline \multirow[b]{2}{*}{ IT(1) } & \multicolumn{2}{|c|}{1 year } & \multicolumn{2}{|c|}{2 years } & \multicolumn{2}{|c|}{3 years } & \multicolumn{2}{|c|}{4 years } \\
\hline & -0.0168 & 0.0148 & -0.0082 & 0.0257 & -0.0103 & 0.0223 & -0.0112 & 0.0221 \\
\hline & [0.0583] & [0.0491] & [0.0607] & [0.0531] & [0.0588] & [0.0515] & [0.0591] & [0.0514] \\
\hline \multirow[t]{2}{*}{$\operatorname{IT}(2)$} & 0.082 & 0.0966 & 0.0845 & 0.0987 & 0.0858 & 0.1002 & 0.0856 & 0.0999 \\
\hline & [0.0539] & [0.0630] & [0.0554] & [0.0653] & [0.0552] & [0.0646] & [0.0553] & [0.0649] \\
\hline \multirow[t]{2}{*}{$\operatorname{Fix}(1)$} & 0.0197 & -0.0065 & 0.0187 & -0.0105 & 0.02 & -0.0084 & 0.0188 & -0.0099 \\
\hline & [0.0151] & [0.0134] & [0.0163] & [0.0161] & [0.0155] & [0.0150] & [0.0161] & [0.0148] \\
\hline \multirow[t]{2}{*}{ Fix(2) } & $0.1512^{\star \star \star}$ & $0.1152^{\star \star}$ & $0.1575^{\star \star \star}$ & $0.1195^{\star \star}$ & $0.1524^{\star \star \star}$ & $0.1138^{\star *}$ & $0.1532^{\star \star \star}$ & $0.1145^{\star \star}$ \\
\hline & [0.0301] & {$[0.0340]$} & {$[0.0317]$} & [0.0358] & [0.0333] & [0.0342] & [0.0346] & [0.0342] \\
\hline \multirow[t]{2}{*}{$\mathrm{MU}(1)$} & $0.0595^{\star \star \star}$ & $0.0774^{\star \star *}$ & $0.0647^{\star \star \star}$ & $0.0797^{\star \star \star}$ & $0.0663^{\star \star \star}$ & 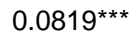 & $0.0659 * \star *$ & $0.0812^{\star * *}$ \\
\hline & [0.0078] & [0.0164] & [0.0105] & [0.0178] & [0.0106] & [0.0185] & {$[0.0106]$} & [0.0182] \\
\hline \multirow[t]{2}{*}{$\mathrm{MU}(2)$} & $0.0776^{\star \star}$ & 0.0077 & $0.0847^{\star \star *}$ & 0.0108 & $0.0861^{\star \star \star}$ & 0.013 & $0.0857^{\star \star *}$ & 0.0121 \\
\hline & [0.0224] & {$[0.0557]$} & {$[0.0176]$} & [0.0579] & [0.0181] & [0.0596] & [0.0180] & {$[0.0600]$} \\
\hline \multirow[t]{2}{*}{ Cons(1) } & -0.0046 & 0.0098 & -0.0173 & -0.0157 & 0.0342 & 0.0277 & -0.0112 & -0.0612 \\
\hline & [0.0382] & [0.0299] & [0.0610] & [0.0420] & [0.0391] & [0.0388] & [0.0082] & [0.0478] \\
\hline \multirow[t]{2}{*}{ Cons(2) } & $0.0898^{\star \star}$ & 0.0591 & $0.3254^{\star \star \star}$ & $0.3680^{\star \star \star}$ & - & - & - & - \\
\hline & [0.0321] & [0.0393] & [0.0094] & {$[0.0100]$} & - & - & - & - \\
\hline \multirow[t]{2}{*}{ Bilateral trade } & & $4.6143^{\star \star}$ & & $4.5081^{\star \star}$ & & $4.5625^{\star \star}$ & & $4.5325^{\star \star}$ \\
\hline & & [1.2171] & & [1.1394] & & [1.1938] & & [1.1778] \\
\hline \multirow[t]{2}{*}{ Distance } & & -0.0437 & & -0.048 & & -0.0464 & & -0.0472 \\
\hline & & {$[0.0441]$} & & [0.0423] & & [0.0434] & & [0.0439] \\
\hline \multirow[t]{2}{*}{ Constant } & $0.2856^{\star \star \star}$ & 0.5735 & $0.2903^{\star * *}$ & 0.6167 & $0.2867^{\star \star \star}$ & 0.6015 & $0.2892^{\star \star *}$ & 0.61 \\
\hline & [0.0204] & {$[0.3599]$} & [0.0102] & [0.3335] & [0.0111] & [0.3473] & [0.0112] & [0.3511] \\
\hline Observations & 960 & 884 & 960 & 884 & 960 & 884 & 960 & 884 \\
\hline R-squared & 0.02 & 0.08 & 0.02 & 0.09 & 0.02 & 0.08 & 0.02 & 0.08 \\
\hline
\end{tabular}

Robust standard errors in brackets. * significant at $10 \%$; ** significant at $5 \%$; *** significant at $1 \%$. 
Table 7: Fiscal stimuli and business cycle synchronization - Baxter-King detrending (minimum duration).

\begin{tabular}{|c|c|c|c|c|c|c|c|c|}
\hline \multirow[b]{3}{*}{$\operatorname{IT}(1)$} & \multicolumn{8}{|c|}{ minimum duration of fiscal consolidation episodes within the 5 -year window periods } \\
\hline & \multicolumn{2}{|c|}{ at least 1 year } & \multicolumn{2}{|c|}{ at least 2 years } & \multicolumn{2}{|c|}{ at least 3 years } & \multicolumn{2}{|c|}{ at least 4 years } \\
\hline & $-0.1544^{\star}$ & -0.1122 & $-0.1568^{*}$ & -0.1071 & $-0.1557^{\star}$ & -0.1109 & $-0.1589 *$ & -0.1136 \\
\hline & {$[0.0711]$} & [0.0618] & [0.0650] & [0.0601] & {$[0.0686]$} & [0.0634] & [0.0691] & [0.0634] \\
\hline \multirow[t]{2}{*}{$\mathrm{IT}(2)$} & 0.1394 & 0.1558 & 0.1419 & 0.1566 & 0.1462 & 0.1625 & 0.1459 & 0.1623 \\
\hline & [0.1470] & [0.1600] & [0.1439] & [0.1585] & [0.1463] & [0.1594] & [0.1465] & [0.1597] \\
\hline \multirow[t]{2}{*}{$\operatorname{Fix}(1)$} & 0.0507 & 0.019 & 0.048 & 0.0083 & 0.056 & 0.0204 & 0.0535 & 0.0186 \\
\hline & [0.0341] & [0.0524] & [0.0293] & [0.0471] & {$[0.0365]$} & [0.0548] & [0.0368] & {$[0.0540]$} \\
\hline \multirow[t]{2}{*}{$\operatorname{Fix}(2)$} & $0.2660^{\star \star \star}$ & $0.2265^{\star \star \star}$ & $0.2763^{\star \star}$ & $0.2441^{\star *}$ & $0.2595^{\star \star}$ & $0.2221^{\star \star}$ & $0.2616^{\star \star}$ & $0.2250^{\star \star}$ \\
\hline & [0.0573] & [0.0410] & [0.0683] & [0.0617] & [0.0608] & [0.0496] & {$[0.0637]$} & [0.0513] \\
\hline \multirow[t]{2}{*}{$\mathrm{MU}(1)$} & $0.1398^{\star *}$ & $0.1557^{\star \star}$ & $0.1507^{\star \star \star}$ & $0.1591^{\star *}$ & $0.1596^{\star \star \star}$ & $0.1754^{\star \star}$ & $0.1584^{\star \star \star}$ & 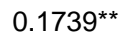 \\
\hline & {$[0.0347]$} & [0.0424] & [0.0302] & [0.0446] & [0.0295] & [0.0420] & [0.0294] & [0.0416] \\
\hline \multirow[t]{2}{*}{$\mathrm{MU}(2)$} & $0.2623^{\star * *}$ & $0.1834^{\star \star}$ & $0.2655^{\star \star \star}$ & $0.1731^{\star *}$ & $0.2777^{\star \star \star}$ & $0.1947^{\star *}$ & $0.2764^{\star \star \star}$ & $0.1935^{\star \star}$ \\
\hline & [0.0185] & [0.0624] & [0.0104] & {$[0.0565]$} & {$[0.0127]$} & [0.0598] & [0.0123] & [0.0597] \\
\hline \multirow[t]{2}{*}{ Cons(1) } & -0.092 & $-0.0804^{*}$ & -0.1019 & -0.116 & 0.0941 & 0.0823 & $0.2260^{* * *}$ & $0.1892^{*}$ \\
\hline & {$[0.0623]$} & [0.0366] & [0.1058] & {$[0.0767]$} & [0.0660] & [0.0425] & [0.0231] & [0.0748] \\
\hline \multirow[t]{2}{*}{ Cons(2) } & $0.1898^{*}$ & $0.1661^{*}$ & $0.3400^{\star \star \star *}$ & $0.3968^{\star \star \star}$ & - & - & - & - \\
\hline & {$[0.0794]$} & [0.0738] & {$[0.0701]$} & [0.0454] & - & - & - & - \\
\hline \multirow[t]{2}{*}{ B-K bilateral trade } & & $4.3899 * *$ & & $4.3491^{\star \star \star}$ & & $4.8907^{\star *}$ & & $4.8435^{\star \star}$ \\
\hline & & [0.9835] & & [0.9197] & & [1.1568] & & [1.1046] \\
\hline \multirow[t]{2}{*}{ Log distance } & & -0.0575 & & -0.068 & & -0.058 & & -0.0584 \\
\hline & & [0.0440] & & [0.0461] & & [0.0464] & & [0.0468] \\
\hline \multirow[t]{2}{*}{ Constant } & $0.2892^{\star * *}$ & 0.6847 & $0.2639 \star \star \star *$ & 0.7514 & $0.2297^{\star \star \star}$ & 0.6313 & $0.2346^{\star \star \star}$ & 0.6394 \\
\hline & {$[0.0247]$} & {$[0.3508]$} & {$[0.0215]$} & [0.3738] & [0.0205] & [0.3865] & [0.0219] & [0.3901] \\
\hline Observations & 950 & 874 & 950 & 874 & 950 & 874 & 950 & 874 \\
\hline R-squared & 0.08 & 0.11 & 0.07 & 0.11 & 0.07 & 0.1 & 0.07 & 0.1 \\
\hline
\end{tabular}

Robust standard errors in brackets * significant at 10\%; ** significant at 5\%**** significant at 1\%. 
Table 8: Fiscal stimuli and business cycle synchronization - Growth detrending (minimum duration). minimum duration of fiscal stimuli episodes within the windows (in years)

\begin{tabular}{|c|c|c|c|c|c|c|c|c|}
\hline \multirow[b]{3}{*}{$\mathrm{IT}(1)$} & \multirow{2}{*}{\multicolumn{2}{|c|}{ at least 1 year }} & & & & & & \\
\hline & & & \multicolumn{2}{|c|}{ at least 2 years } & \multicolumn{2}{|c|}{ at least 3 years } & \multicolumn{2}{|c|}{ at least 4 years } \\
\hline & -0.0146 & 0.0156 & -0.0086 & 0.0256 & -0.0107 & 0.0218 & -0.0112 & 0.0221 \\
\hline & [0.0623] & [0.0501] & [0.0606] & [0.0531] & [0.0588] & [0.0514] & [0.0591] & [0.0514] \\
\hline \multirow[t]{2}{*}{$\mathrm{IT}(2)$} & 0.0817 & 0.0966 & 0.0845 & 0.0985 & 0.0858 & 0.1001 & 0.0856 & 0.0999 \\
\hline & [0.0531] & [0.0629] & [0.0559] & [0.0655] & [0.0553] & [0.0647] & [0.0553] & [0.0649] \\
\hline \multirow[t]{2}{*}{$\operatorname{Fix}(1)$} & 0.0191 & -0.0059 & 0.0183 & -0.0112 & 0.0198 & -0.0089 & 0.0188 & -0.0099 \\
\hline & [0.0165] & {$[0.0135]$} & [0.0165] & [0.0171] & {$[0.0157]$} & [0.0152] & [0.0161] & [0.0148] \\
\hline \multirow[t]{2}{*}{$\operatorname{Fix}(2)$} & $0.1534^{\star \star \star}$ & 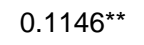 & $0.1573^{\star \star \star}$ & $0.1202^{\star \star}$ & $0.1526^{\star \star \star}$ & $0.1144^{\star \star}$ & $0.1532^{\star \star \star}$ & $0.1145^{\star \star}$ \\
\hline & [0.0284] & [0.0294] & [0.0309] & [0.0367] & [0.0336] & {$[0.0342]$} & {$[0.0346]$} & [0.0342] \\
\hline \multirow[t]{2}{*}{$\mathrm{MU}(1)$} & 0.0580 *** & $0.0771^{* * *}$ & $0.0649 * \star \star$ & $0.0792^{\star \star \star}$ & $0.0662^{\star \star \star}$ & $0.0816^{\star \star \star}$ & $0.0659 * \star \star$ & $0.0812^{\star \star \star}$ \\
\hline & [0.0077] & [0.0153] & [0.0107] & [0.0184] & {$[0.0106]$} & [0.0186] & [0.0106] & [0.0182] \\
\hline \multirow[t]{2}{*}{$\mathrm{MU}(2)$} & $0.0768^{\star *}$ & 0.0091 & $0.0853^{\star \star \star}$ & 0.0102 & 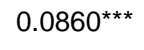 & 0.0127 & $0.0857^{\star \star \star}$ & 0.0121 \\
\hline & [0.0212] & {$[0.0577]$} & {$[0.0180]$} & [0.0585] & [0.0181] & [0.0599] & {$[0.0180]$} & {$[0.0600]$} \\
\hline \multirow[t]{2}{*}{ Cons(1) } & -0.02 & -0.0024 & -0.0123 & -0.0165 & 0.0257 & 0.0106 & -0.0112 & -0.0612 \\
\hline & [0.0337] & [0.0178] & [0.0634] & [0.0413] & [0.0311] & [0.0399] & [0.0082] & [0.0478] \\
\hline \multirow[t]{2}{*}{ Cons(2) } & $0.1053^{\star *}$ & 0.0764 & $0.3330 * \star *$ & $0.3782^{\star * *}$ & - & - & - & - \\
\hline & [0.0348] & [0.0512] & {$[0.0446]$} & {$[0.0236]$} & - & - & - & - \\
\hline \multirow[t]{2}{*}{ B-K bilateral trade } & & $4.5905^{\star \star}$ & & $4.4908^{\star \star}$ & & $4.5511^{\star \star}$ & & $4.5325^{\star *}$ \\
\hline & & [1.1454] & & [1.1218] & & [1.1841] & & [1.1778] \\
\hline \multirow[t]{2}{*}{ Log distance } & & -0.0431 & & -0.0484 & & -0.0466 & & -0.0472 \\
\hline & & [0.0443] & & [0.0422] & & [0.0437] & & [0.0439] \\
\hline \multirow[t]{2}{*}{ Constant } & $0.2958^{\star \star \star}$ & 0.5734 & $0.2902^{\star \star \star}$ & 0.6211 & 0.2870 *** & 0.6039 & $0.2892^{\star \star *}$ & 0.61 \\
\hline & [0.0157] & {$[0.3545]$} & {$[0.0141]$} & {$[0.3326]$} & {$[0.0110]$} & {$[0.3502]$} & {$[0.0112]$} & {$[0.3511]$} \\
\hline Observations & 960 & 884 & 960 & 884 & 960 & 884 & 960 & 884 \\
\hline R-squared & 0.03 & 0.09 & 0.02 & 0.09 & 0.02 & 0.08 & 0.02 & 0.08 \\
\hline
\end{tabular}

Robust standard errors in brackets. * significant at 10\%; ${ }^{\star}$ significant at $5 \% ;{ }^{* \star *}$ significant at $1 \%$. 